Article

\title{
Zinc Recovery from Steelmaking Dust by Hydrometallurgical Methods
}

\author{
Piotr Palimąka *, Stanisław Pietrzyk, Michał Stępień, Katarzyna Ciećko and Ilona Nejman
}

Faculty of Non-Ferrous Metals, AGH University of Science and Technology, 30-059 Krakow, Poland; pietstan@agh.edu.pl (S.P.); mstepien@agh.edu.pl (M.S.); kat.ciecko@gmail.com (K.C.); inejman@agh.edu.pl (I.N.)

* Correspondence: palimaka@agh.edu.pl; Tel.: +48-126-172-671

Received: 17 June 2018; Accepted: 16 July 2018; Published: 18 July 2018

\begin{abstract}
Hydrometallurgical recovery of zinc from electric arc furnace dust was investigated on a laboratory scale, using aqueous sodium hydroxide solution as a leaching agent. Special attention was paid to the effect of $\mathrm{NaOH}$ concentration, temperature and liquid/solid phase ratio on the zinc leachability. It was found that all tested factors increased the leachability, with the maximum efficiency of $88 \%$ obtained in a $6 \mathrm{M} \mathrm{NaOH}$ solution at a temperature of $80^{\circ} \mathrm{C}$ and the liquid/solid phase ratio of 40 . The test results confirmed the high selectivity of the zinc leaching agent. In spite of this, complete recovery of zinc from steelmaking dust has proved to be very difficult due to the occurrence of this element in the form of stable and sparingly soluble $\mathrm{ZnFe}_{2} \mathrm{O}_{4}$ ferrite. Purification of the solution by cementation and electrolysis gave zinc of purity $99.88 \%$ in powder form.
\end{abstract}

Keywords: steelmaking dust; zinc recycling; alkaline leaching; electric arc furnace

\section{Introduction}

One of the commonly used techniques to protect steel surfaces from corrosion is galvanizing. Almost $50 \%$ of the world's zinc production is consumed for this purpose. Worn steel elements are usually sent to metallurgical plants and are subjected to a remelting process in electric arc furnaces (EAF). During this process, zinc is evaporated, oxidized and then, as solid $\mathrm{ZnO}$, transferred to dedusting devices. One ton of smelted steel scrap produces about $15-25 \mathrm{~kg}$ of dust, in which the content of zinc is 15-40\% [1]. The dusts additionally contain a significant amount of iron (about $20 \%$ ) and other elements such as cadmium, nickel, chromium, manganese, carbon, tin, antimony and copper. The storage of this type of waste is associated with serious threats to the natural environment, as metals can leach out to surface and groundwater, contaminating the environment [2]. Moreover, following accumulation in organisms such as plants and animals, they reach humans. Since the metals do not decompose, they can bioaccumulate once they are absorbed [3]. Therefore, the waste should be recycled to the steelmaking process, which is not currently possible due to the high content of zinc. On the other hand, a significant iron content eliminates the possibility of treating the steel dust as a raw material for the traditional hydrometallurgical zinc manufacturing process.

Current technologies for steel dust processing are focused on pyrometallurgical methods, and consist mainly of high-temperature reduction of $\mathrm{ZnO}$ contained in dust and secondary oxidation of $\mathrm{Zn}$ in the gas phase. Figure 1 shows the pyro-and hydrometallurgical methods for steelmaking dust processing currently used on an industrial and pilot scale. The Waelz kiln process remains the predominant method for processing dust, with over $85 \%$ of the market [4]. Any other pyrometallurgical process, indicated in Figure 1, results in zinc in the form of $\mathrm{ZnO}$, which is fed to the traditional process of sulfate electrolysis or Imperial Smelting Process (ISP). 


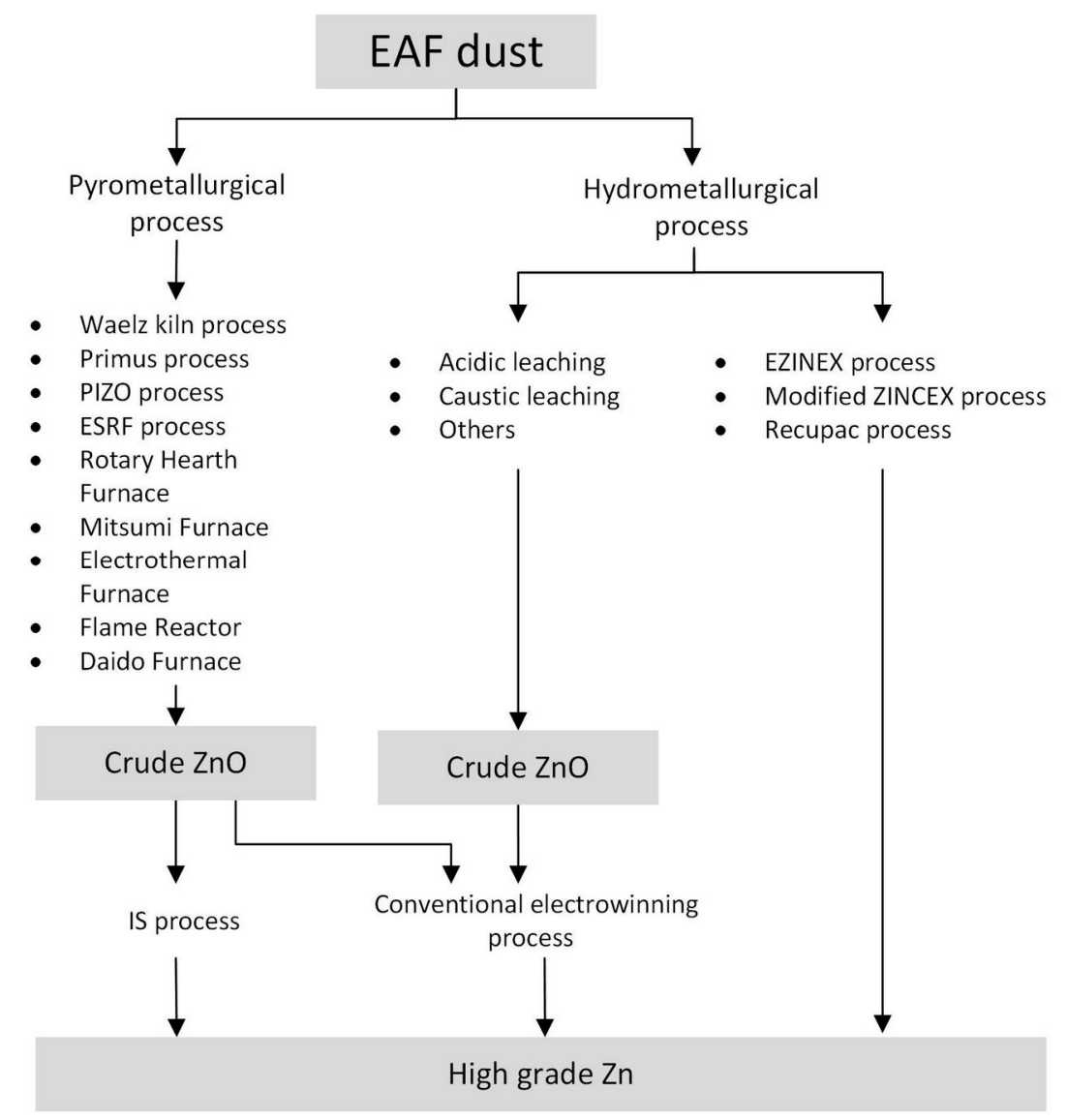

Figure 1. Schematic presentation of electric arc furnace dust treatment [3-7].

The attempt to implement a comprehensive and waste-free process described in References $[3,5]$ was undertaken by a plant in Poland. The pilot installation that has been launched allows two fully usable products to be made in a shaft furnace. The first product is $\mathrm{Zn}$, in the form of $\mathrm{ZnO}$, removed from properly formed briquettes and captured in dedusting devices. The second product includes zinc-free sintered briquettes, which can be used in steelmaking. In this way, no waste is generated in the process.

Hydrometallurgical processes are not as popular as pyrometallurgical methods, but there are several installations converting EAF dust on an industrial scale. One of the currently used technologies is the EZINEX process, which involves ammonia leaching of dust, cementation-based purification of the solution and zinc separation through electrolysis. In recent years, the process has been modified with high-temperature pre-treatment of zinc-bearing material (fuming in an induction furnace). As a result of this process, raw zinc oxide is subjected to a hydrometallurgical treatment, and the integrated technology is called ENDUTEC/EZINEX [6]. Another process (Modified Zincex Process) is a modification and simplification of the former process (Zincex) using atmospheric leaching $\left(\mathrm{H}_{2} \mathrm{SO}_{4}\right.$ solution), solvent extraction and conventional electrowinning, in order to resolve impurity difficulties and recover Special High Grade (SHG) zinc ingots [8]. In turn, Recupac has developed a patented recycling process to extract marketable iron and zinc compounds from EAF dust using proven hydrometallurgical technology. The zinc and iron are recovered, and the iron oxide is used to make industrial pigments. Many processes developed on a laboratory, pilot or major scale have not been implemented in industry, or, for indefinite reasons, have been delayed after several years (Cebedeau, Cardif, AMAX) [9]. The biggest problem in hydrometallurgical processes is the maximization of zinc recovery with simultaneous inhibition of iron extraction into the solution [10]. Since zinc occurs in the dust as $\mathrm{ZnO}$ and $\mathrm{ZnFe}_{2} \mathrm{O}_{4}$, the key problem is how to extract it from the zinc ferrite and transfer it to 
the solution. If zinc in the dust is mainly present in the form of $\mathrm{ZnO}$, high leaching efficiency is to be expected. If, in turn, zinc is in large part bound in $\mathrm{ZnFe}_{2} \mathrm{O}_{4}$-a phase of very high stability-then zinc recovery may be low [10]. Generally, hydrometallurgical processes involve leaching of steelmaking dust and extraction of zinc from the solution in a metallic form or as zinc compounds. The main goals are to obtain the end product of the highest purity, develop a method for the management of intermediate products formed during hydrometallurgical processing, and reduce zinc content in the processed EAF dust to a level that would allow its recycling for use in the steelmaking industry.

Until now, most of the attention in studies of the leaching process has been paid to the use of sulfuric acid and caustic soda as leaching agents. The advantages of using sulfuric acid include high dissolution kinetics, availability and a modest price, as well as the possibility of using low concentrations and a well-known process of electrolysis to obtain metallic zinc, with regeneration of the acid. Conversely, the biggest disadvantage of using sulfuric acid as a leaching agent is the lack of selectivity towards other metals found in steelmaking dust. This applies mainly to iron, which can sometimes have a content in steelmaking dust much higher than that of zinc. This results in high consumption of the leaching agent combined with the need to purify the leach solution from significant amounts of $\mathrm{Fe}$, which is both complex and difficult. Iron hinders the cementation of copper, cadmium and cobalt [9]. It is also necessary to control $\mathrm{pH}$ to avoid hydrolysis and $\mathrm{Zn}(\mathrm{OH})_{2}$ precipitation.

The main advantage of using an alkaline leaching agent is its selectivity towards zinc over iron, which practically eliminates the difficult and complicated process of iron removal from the electrolyte. It is also possible to separate lead from zinc, which may be used as an additional intermediate product and raw material for the recovery of this metal. Therefore, the use of $\mathrm{NaOH}$ as a leaching agent seems to be a promising alternative for the processing of steelmaking dust, although alkaline leaching agents also have some disadvantages. The most important include the high concentration necessary to obtain significant zinc leaching efficiency, a higher price compared to sulfuric acid, and the difficult recovery of the solution.

Despite many problems, the hydrometallurgical methods of steelmaking dust processing are much more attractive due to lower operating costs and energy expenditure. Problems related to the high zinc leaching rate and effective extraction from the solution are still a challenge.

Results of research on EAF dust leaching in $\mathrm{NaOH}$ solutions that have been published in recent years indicate a strong dependence of some parameters on leaching efficiency. Mordoğan et al. [10] investigated leaching in solutions with a low concentration of $\mathrm{NaOH}(3.75 \mathrm{M})$ at ambient temperatures. The effects were poor; only $21.45 \%$ of zinc was extracted to the solution. Xia and Pickles [11] and Dutra et al. [12] obtained leaching efficiency of about $74 \%$ at higher concentrations of $\mathrm{NaOH}(6 \mathrm{M})$ and temperature $\left(90^{\circ} \mathrm{C}\right)$. Orhan [13] attempted to use even more concentrated solution and a higher temperature $\left(10 \mathrm{M} \mathrm{NaOH}, 95^{\circ} \mathrm{C}\right)$, and achieved up to $85 \% \mathrm{Zn}$ recovery. Previous results show that the sodium hydroxide concentration and leaching temperature have significant influence on the dissolution of zinc from the EAF dust. Other parameters such as liquid to solid ratio, particle size and agitation speed were also investigated in the above research, but it was found that these parameters had relatively insignificant influence on the extraction process.

Therefore, this study was undertaken to determine the optimal conditions for zinc extraction from EAF dust using caustic soda solutions. The results of the cementation process and electrolysis of the chosen solution, after leaching of dust, were also obtained.

\section{Methods}

\subsection{Leaching}

The leaching process was carried out in two stages. The aim of the first stage, involving leaching in water, was to remove chlorine from the material. This is an indispensable step because, during the main leaching process, the presence of chlorine (and also of $\mathrm{Na}, \mathrm{K}, \mathrm{Ca}$ ) in the dust causes high consumption of the leaching agent and risk of harmful chlorine being released during electrolysis. The liquid/solid 
ratio during leaching was 20 and the temperature was kept at $60^{\circ} \mathrm{C}$. The process lasted $120 \mathrm{~min}$ using mechanical stirring at $400 \mathrm{rpm}$. After water leaching, the material was vacuum filtered. Then, after washing and drying, the residue was subjected to alkaline leaching. The aim of this operation was to transfer as much zinc as possible from the EAF dust to the solution. Sodium hydroxide was used as the leaching agent. The variable parameters investigated for the leaching process included $\mathrm{NaOH}$ concentration, temperature and the liquid/solid ratio $(\mathrm{L} / \mathrm{S})$. These parameters are summarized in Table 1.

Table 1. The parameter values for alkaline leaching of Electric Arc Furnace (EAF) dust.

\begin{tabular}{cc}
\hline Parameter & Value \\
\hline NaOH Concentration, $\mathrm{M}$ & $2,4,6$ \\
Temperature, ${ }^{\circ} \mathrm{C}$ & $20,50,80$ \\
Liquid-solid ratio, $\mathrm{cm}^{3} / \mathrm{g}$ & $10,20,30,40$ \\
Stirring speed, $\mathrm{rpm}$ & 400 \\
Time, $\mathrm{min}$ & 120 \\
\hline
\end{tabular}

The experiments were carried out in an $800 \mathrm{~mL}$ glass beaker placed on a heating plate. The temperature was controlled to the nearest $1{ }^{\circ} \mathrm{C}$ and kept constant using a sensor, protected by a quartz shield, placed in the solution. The duration of each leaching experiment was $120 \mathrm{~min}$. During this process, $4 \mathrm{~mL}$ samples of the solution were taken at 5, 15, 30, 60 and $120 \mathrm{~min}$. Each sample taken was filtered and then subjected to chemical analysis using X-ray fluorescence (XRF) (MiniPal 4, PANalytical B.V., Espoo, Finland). Analysis of the concentration of metals in the solution was based on a multi-point calibration curve. The efficiency of zinc extraction into the solution was calculated from Equation (1):

$$
L_{e}=\left(m_{\mathrm{Zn}, t} / m_{\mathrm{Zn}, 0}\right) \times 100 \%
$$

where: $L_{e}(\%)$ is the zinc extraction efficiency, $m_{\mathrm{Zn}, t}(\mathrm{~g})$ is the zinc content in the solution after leaching time $t$, and $m_{\mathrm{Zn}, 0}(\mathrm{~g})$ is the zinc content in the sample before leaching.

\subsection{Cementation}

The cementation-based purification of the solution was carried out with a $99.95 \%$ pure zinc metal plate, keeping the process temperature at a level of $60{ }^{\circ} \mathrm{C}$ and stirring the solution with a magnetic stirrer. The cementation time was $70 \mathrm{~min}$. During the experiment, samples for analysis were taken every $3 \mathrm{~min}$ (during the first $15 \mathrm{~min}$ of the experiment), then every $5 \mathrm{~min}$ (up to $30 \mathrm{~min}$ of the experiment) and at 50 and $70 \mathrm{~min}$.

\subsection{Electrolysis}

The electrolysis was carried out for $90 \mathrm{~min}$ at a current density of $250 \mathrm{~A} / \mathrm{m}^{2}$ and a temperature of $25^{\circ} \mathrm{C}$. Graphite was used as the material of the anode, while the cathode was made of stainless steel. The current efficiency was calculated from Equation (2):

$$
\eta=\left(m_{\mathrm{Zn}} /(k \times I \times t)\right) \times 100 \%
$$

where: $\eta(\%)$ is the current efficiency, $m_{\mathrm{Zn}}(\mathrm{g})$ is the mass of zinc after electrolysis, $k$ is the electrochemical equivalent, $I(\mathrm{~A})$ is the current and $t(\mathrm{sec})$ is the electrowinning time.

\section{Materials}

The steelmaking dust used in the study was obtained from a Polish steel plant. All the experiments were carried out on dust in the form of finely divided fractions (less than $100 \mu \mathrm{m}$ ) with a moisture content of $5 \%$ (estimated from a $24 \mathrm{~h}$ drying test at $105{ }^{\circ} \mathrm{C}$ ). The chemical and mineralogical compositions of the dust were determined by Microwave Plasma Atomic Emission Spectroscopy 
(MP-AES) (MP-AES 4200, Agilent, Penang, Malaysia), and Scanning Electron Microscopy (SEM) (Hitachi, Tokyo, Japan) and X-ray diffraction (XRD) (MiniFlex II, Rigaku, Tokyo, Japan), respectively. The composition and morphology of the dust strongly depends on the quality of the scrap and on the mode of operation of the electric furnace [3]. Typical EAF dust particles obtained by scanning electron microscopy with analysis of a selected particle, are presented in Figure 2.

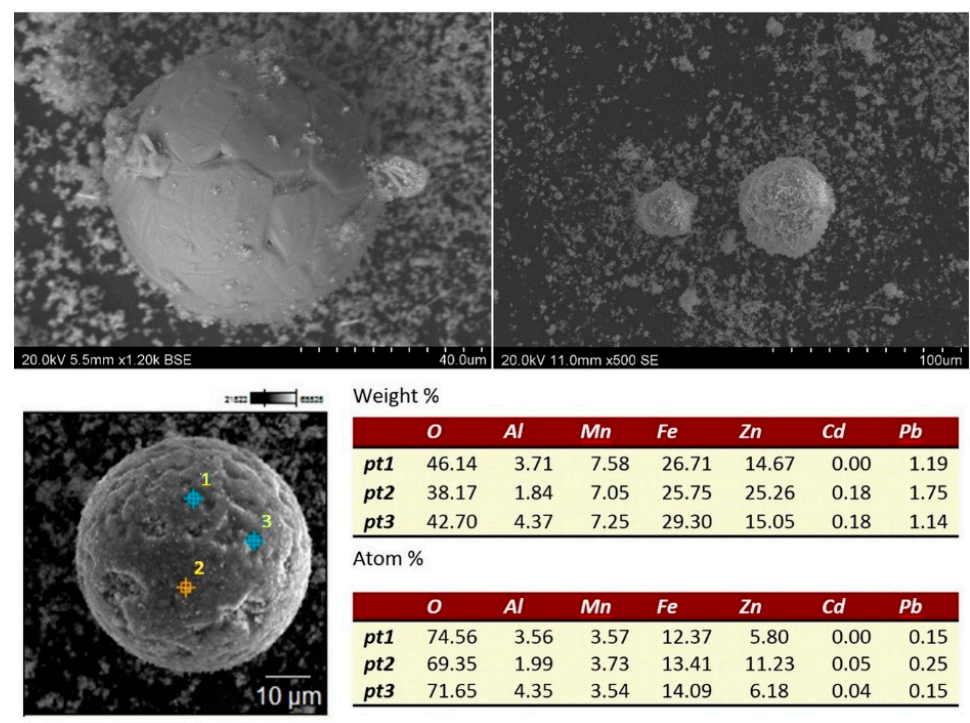

Figure 2. Spherical Electric Arc Furnace (EAF) dust particles and chemical analysis using Scanning Electron Microscope (SEM).

The presence of spherical particles rich in iron, oxygen and zinc was observed. The results of the chemical composition of EAF dust are given in Table 2. The X-ray diffraction pattern of the EAF dust is shown in Figure 3.

Table 2. Chemical composition of the main elements present in the dust.

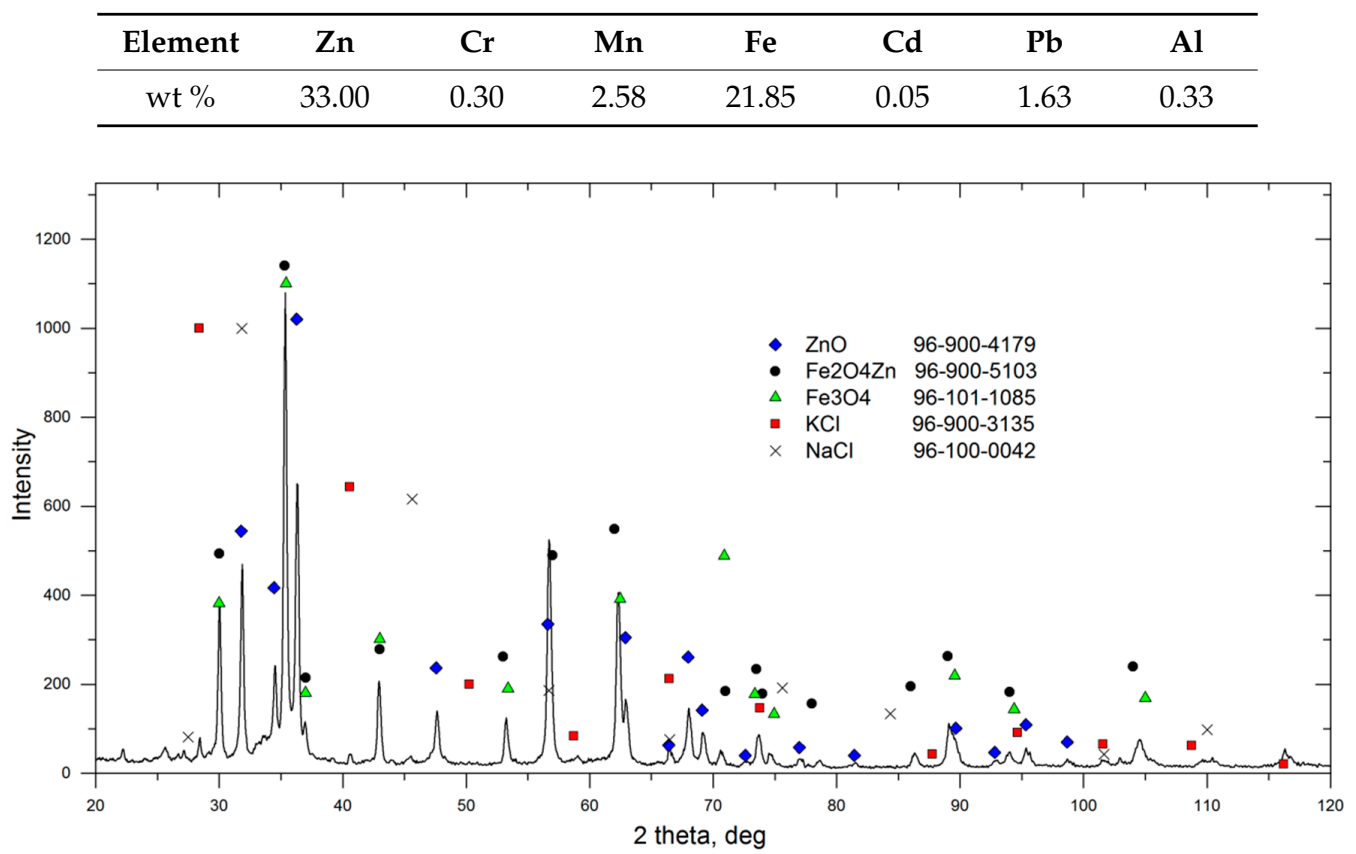

Figure 3. X-ray diffraction analysis of EAF dusts. 
Five major phases were identified: franklinite, magnetite, zincite, and sodium and potassium chlorides. The identified chlorides were a residue generated from chlorinated rubber coatings present in plastic admixtures (including polyvinyl chloride and synthetic rubber) in the charge melted to generate the EAF dust. These chlorides are volatile under the process conditions used and evaporate easily, which explains their presence in the dust. Many other compounds have also been identified in the dust $[11,12,14,15]$, but being present in insufficient quantities, these were difficult to detect.

\section{Results}

\subsection{Leaching}

In this study, the effect of 2, 4 and $6 \mathrm{M} \mathrm{NaOH}$ on the zinc extraction efficiency was investigated. The tests were limited to a concentration of $6 \mathrm{M}$, because the viscosity of solutions with higher $\mathrm{NaOH}$ content increased too much, hindering further processing operations.

The main reactions occurring during leaching of dust can be written in the form of reactions (3) and (4):

$$
\begin{gathered}
\mathrm{ZnO}_{(\mathrm{s})}+2 \mathrm{NaOH}_{(\mathrm{aq})} \rightarrow \mathrm{Na}_{2} \mathrm{ZnO}_{2(\mathrm{aq})}+\mathrm{H}_{2} \mathrm{O}_{(\mathrm{l})} \\
\mathrm{PbO}_{(\mathrm{s})}+2 \mathrm{NaOH}_{(\mathrm{aq})} \rightarrow \mathrm{Na}_{2} \mathrm{PbO}_{2(\mathrm{aq})}+\mathrm{H}_{2} \mathrm{O}_{(\mathrm{l})}
\end{gathered}
$$

The high stability of ferrites means that only some of them can dissolve in $\mathrm{NaOH}$ solutions, according to reaction (5) [10]:

$$
\mathrm{ZnFe}_{2} \mathrm{O}_{4}+2 \mathrm{NaOH}_{(\mathrm{aq})} \rightarrow \mathrm{Na}_{2} \mathrm{ZnO}_{2(\mathrm{aq})}+\mathrm{H}_{2} \mathrm{O}_{(\mathrm{l})}+\mathrm{Fe}_{2} \mathrm{O}_{3(\mathrm{~s})}
$$

Sample leaching curves for all $\mathrm{NaOH}$ concentrations, limit values for temperature and $\mathrm{L} / \mathrm{S}$ conditions $\left(20\right.$ and $80^{\circ} \mathrm{C}$ and L/S of 10 and 40) are shown in Figure 4.

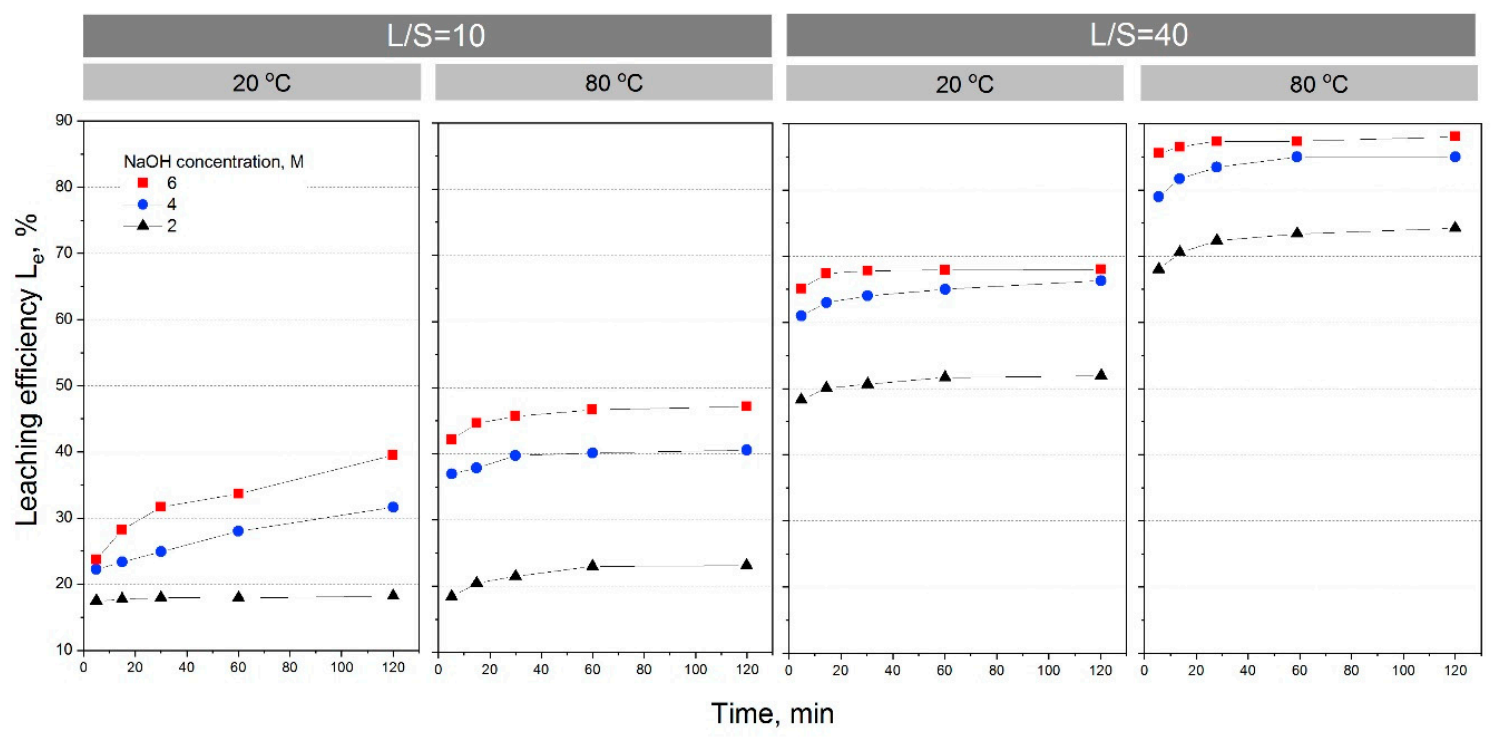

Figure 4. Leaching efficiency for zinc at different leaching conditions of $\mathrm{NaOH}$ concentration $(2,4$, $6 \mathrm{M})$, temperature $\left(20\right.$ and $\left.80^{\circ} \mathrm{C}\right)$ and liquid/solid (L/S) ratio (10 and 40).

The leaching results obtained for the limit parameter values lead to the conclusion that leaching in $2 \mathrm{M} \mathrm{NaOH}$ and $\mathrm{L} / \mathrm{S}=10$ offers a very modest process efficiency, giving a maximum of $24 \%$. During leaching at $20^{\circ} \mathrm{C}$ in 4 and $6 \mathrm{M}$ solutions $(\mathrm{L} / \mathrm{S}=10)$, a continuous increase in the zinc extraction was observed, which means that these solutions have the potential to dissolve more $\mathrm{Zn}$, but in a time much longer than that used in the experiments. Increasing the temperature to $80{ }^{\circ} \mathrm{C}$ increases the 
zinc extractions to 40 and $45 \%$ for 4 and $6 \mathrm{M} \mathrm{NaOH}$, respectively, after only $30 \mathrm{~min}$. Further increases in the leaching time do not result in higher zinc extractions. For $\mathrm{L} / \mathrm{S}=40$, the extractions are much higher, giving 68 and $88 \%$, after $120 \mathrm{~min}$ in $6 \mathrm{M} \mathrm{NaOH}$, at $20^{\circ} \mathrm{C}$ and $80^{\circ} \mathrm{C}$, respectively. Table $\mathrm{A} 1$ in Appendix A summarizes all the results of zinc extraction and its concentration obtained after $120 \mathrm{~min}$ for each leaching test. Figures 5 and 6 show these results in graphical form.
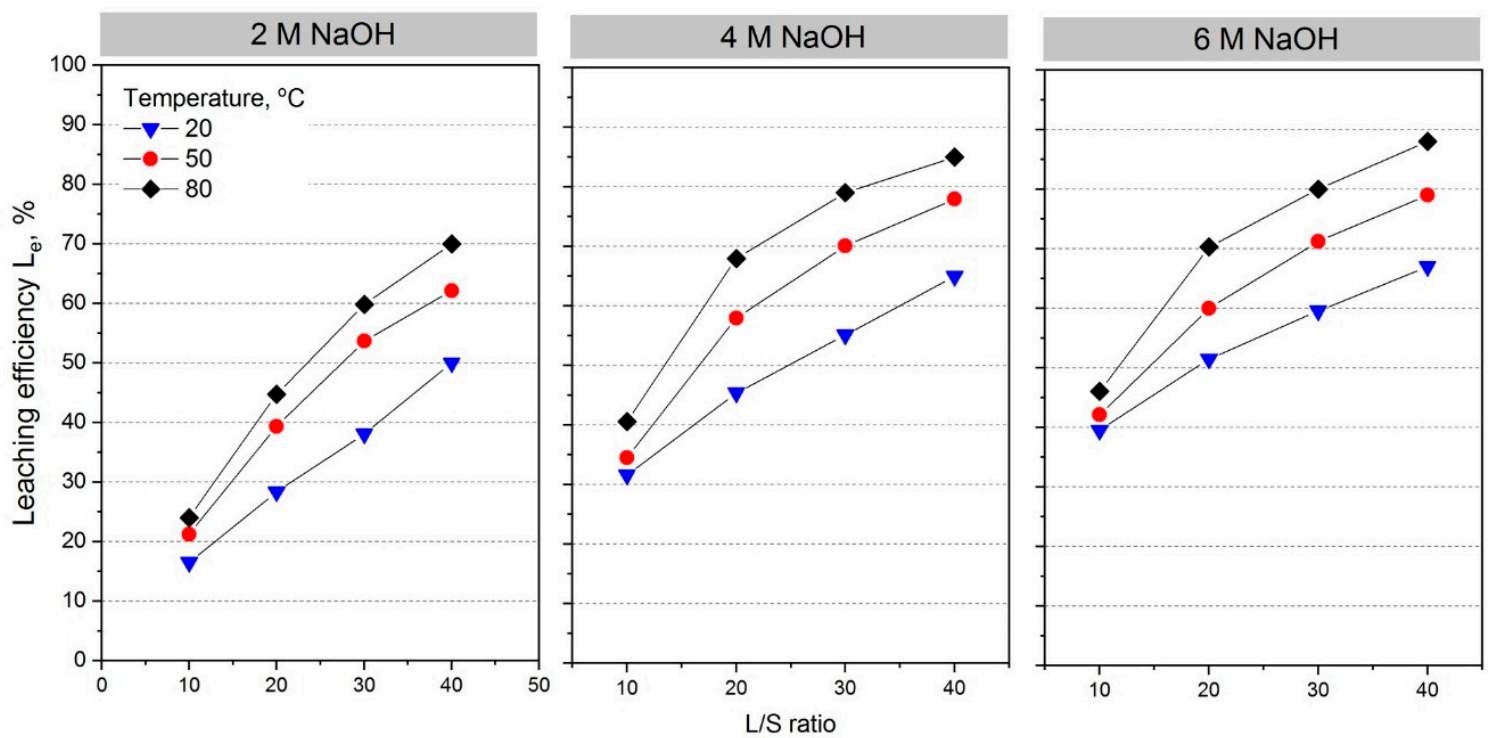

Figure 5. Leaching efficiency for zinc as a function of L/S ratio for different $\mathrm{NaOH}$ concentrations and temperature.
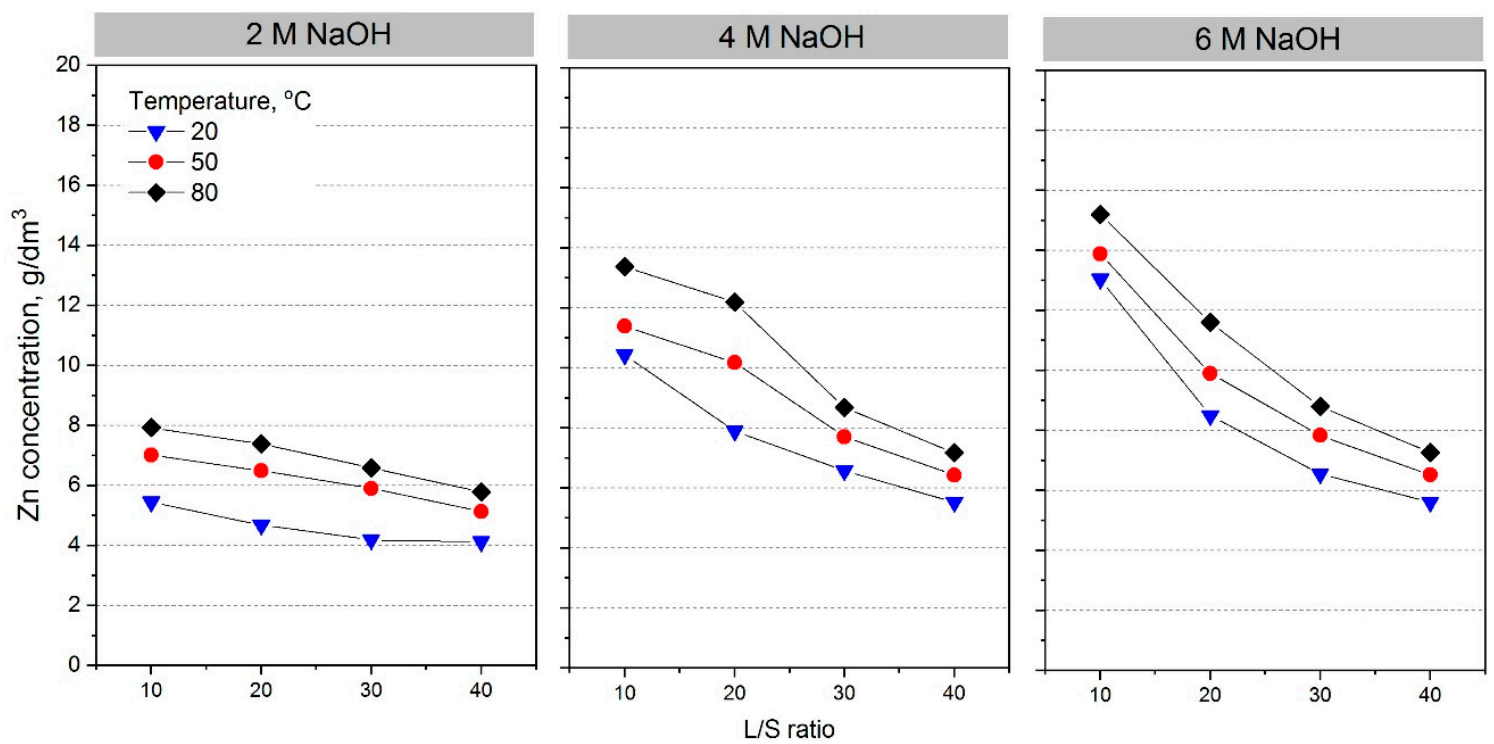

Figure 6. Zinc concentration as a function of $\mathrm{L} / \mathrm{S}$ ratio for different $\mathrm{NaOH}$ concentrations and temperature.

The results obtained show that zinc leaching efficiency depends on all the examined factors, i.e., time, temperature, $\mathrm{NaOH}$ concentration and the solid phase content in the leaching solution. At each temperature, the increase in concentration from $2 \mathrm{M}$ to $4 \mathrm{M} \mathrm{NaOH}$ increased zinc extraction by a dozen percentage points (13.3-23.4). For further increase in $\mathrm{NaOH}$ concentration, the efficiency gains were much lower (0.9-7.9 pp). This may be due to either higher viscosity of the solution 
and the resultant difficulty in transporting the reactants to and from the reaction surface, or from achieving the maximum extraction under the conditions employed. Additionally, the smallest effect of temperature was observed in solutions with a high solid phase content $(\mathrm{L} / \mathrm{S}=10)$. In this case, raising the temperature by $30{ }^{\circ} \mathrm{C}$ increased the efficiency of the zinc leaching process by a maximum of $6 \mathrm{pp}$. In each subsequent leaching test, in which the liquid phase content was increased with respect to the solid phase, the effect of temperature was stronger, and the maximum increase in leaching efficiency was about $15.6 \mathrm{pp}$ for $\mathrm{L} / \mathrm{S}=30$ and $2 \mathrm{M} \mathrm{NaOH}$. Although increasing the liquid phase content in the leached slurry had a beneficial effect on the dust leaching efficiency in terms of metal extraction into the solution in general, the concentration of zinc in the solution actually decreased with increased $\mathrm{L} / \mathrm{S}$. The increase of $\mathrm{L} / \mathrm{S}$ from 10 to 40 in the case of leaching in $2 \mathrm{M} \mathrm{NaOH}$ at $80^{\circ} \mathrm{C}$ resulted in the drop of zinc concentration from $7.93 \mathrm{~g} / \mathrm{dm}^{3}$ to $5.78 \mathrm{~g} / \mathrm{dm}^{3}$, i.e., about $27 \%$. At the highest $\mathrm{NaOH}$ concentration of $6 \mathrm{M}$, the decrease in zinc concentration associated with dilution of the solution was $52 \%$ (from 15.19 to $7.26 \mathrm{~g} / \mathrm{dm}^{3}$ ). Erdem et al. [16] observed that waste materials containing zinc in the form of $\mathrm{ZnFe}_{2} \mathrm{O}_{4}$ were difficult to leach because franklinite is very stable and poorly soluble in most types of alkaline solutions. They achieved a maximum leachability of $21.47 \%$ during leaching at $25{ }^{\circ} \mathrm{C}$ for $120 \mathrm{~min}$, using a stirring speed of $300 \mathrm{rpm}, \mathrm{L} / \mathrm{S}=5$ and $\mathrm{NaOH}$ concentration of $15 \%$. In the present study, it was found that high solid phase content results in low leaching efficiency of $\mathrm{Zn}$, therefore the results obtained by Erdem et al. [16] appear to be lower than those which can be achieved. The maximum zinc extraction $(88.0 \%)$ in this study was obtained for $6 \mathrm{M} \mathrm{NaOH}$ at $80^{\circ} \mathrm{C}$ and $\mathrm{L} / \mathrm{S}=40$. Figure 7 presents a diffractogram of EAF dust samples before and after leaching under selected process conditions.

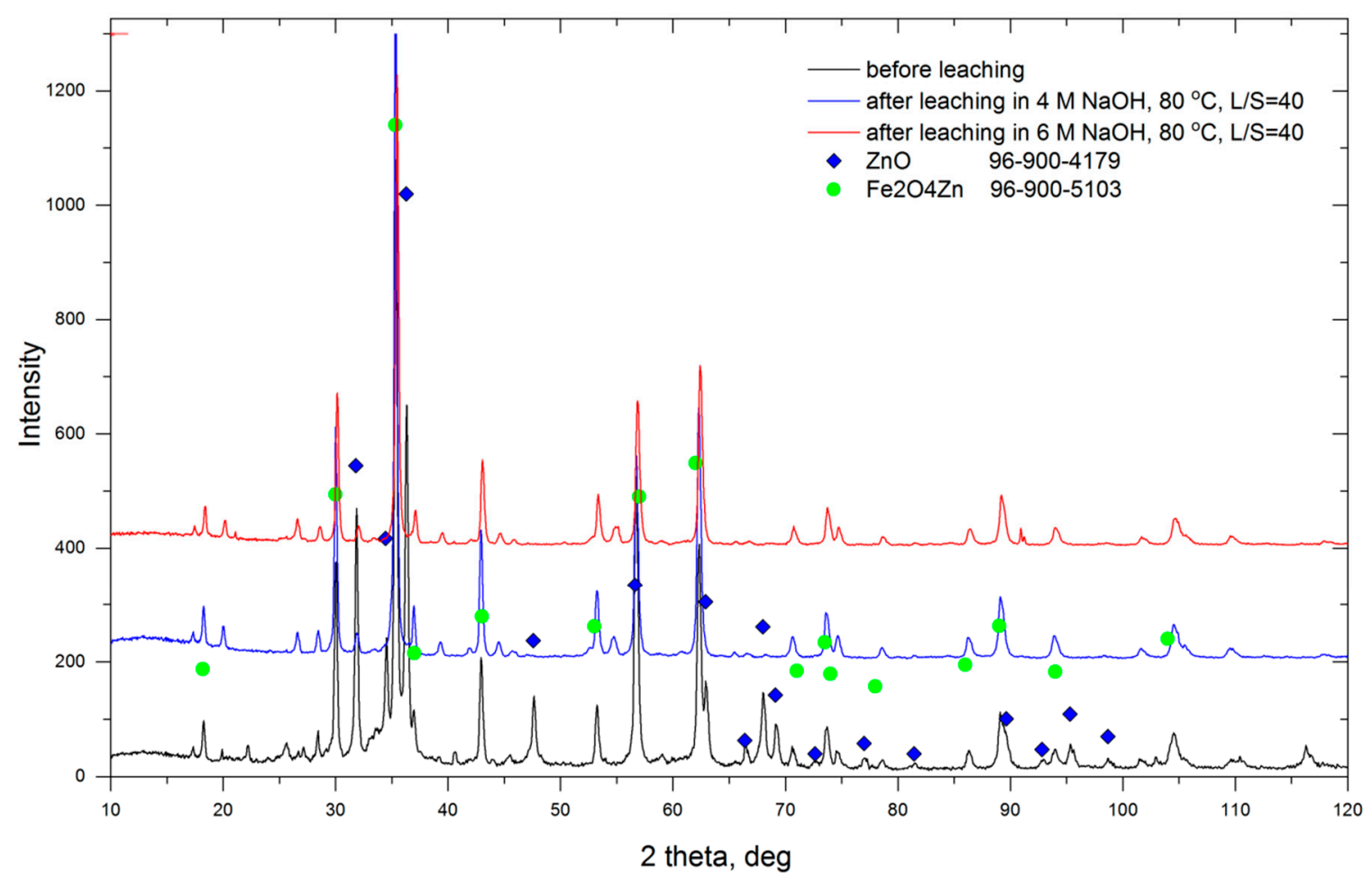

Figure 7. X-ray diffraction analysis of EAF dusts before and after leaching (in 4 and $6 \mathrm{M} \mathrm{NaOH}$, $\mathrm{L} / \mathrm{S}=40$, temp. $=80^{\circ} \mathrm{C}$, time $=120 \mathrm{~min}$ ).

XRD analysis of the residue obtained after leaching in $4 \mathrm{M} \mathrm{NaOH}$ at $80^{\circ} \mathrm{C}$ with $\mathrm{L} / \mathrm{S}=40$ showed that virtually all zinc, present in the form of $\mathrm{ZnO}$, was removed from the dust. An increase in $\mathrm{NaOH}$ concentration from 4 to $6 \mathrm{M}$ increased the leaching efficiency by a very small extent only, i.e., by $3 \mathrm{pp}$. It was, however, an indication that zinc in the form of $\mathrm{ZnFe}_{2} \mathrm{O}_{4}$ was being dissolved according to 
reaction (5), although this process was slow. The dissolution of franklinite was suggested by the lower intensity of franklinite peaks in the diffractogram for the sample leached in $6 \mathrm{M} \mathrm{NaOH}$ at $80{ }^{\circ} \mathrm{C}$ with $\mathrm{L} / \mathrm{S}=40$ (Figure 7). Analysis of the concentrations of other elements in the leach solution confirmed good selectivity of $\mathrm{NaOH}$ towards zinc. In none of the conducted leaching tests did the concentration of iron in the solution exceed $20 \mathrm{mg} / \mathrm{dm}^{3}$. The only dust component that could dissolve in larger amounts according to reaction (4) is lead. Its concentration under the optimal for zinc leaching conditions $\left(6 \mathrm{M} \mathrm{NaOH}\right.$ at $80{ }^{\circ} \mathrm{C}$ with $\left.\mathrm{L} / \mathrm{S}=40\right)$ did not exceed $550 \mathrm{mg} / \mathrm{dm}^{3}$, though even this concentration is quite significant and might affect the process of electrolysis (i.e., contaminate the zinc cathode). The concentration of other metals ( $\mathrm{Cr}, \mathrm{Mn}, \mathrm{Cd})$ in all leaching tests was low and generally below $40 \mathrm{mg} / \mathrm{dm}^{3}$, or much lower. The tested leaching parameters had no specific effect on the concentrations of these metals. Table 3 outlines the results of the solution analysis after leaching at $80^{\circ} \mathrm{C}(6 \mathrm{M} \mathrm{NaOH} ; \mathrm{L} / \mathrm{S}=10)$. This particular solution was selected for further treatment, as it had the highest concentration of zinc.

Table 3. Leach solution composition after $120 \mathrm{~min}\left(6 \mathrm{M} \mathrm{NaOH} ; 80^{\circ} \mathrm{C} ; \mathrm{L} / \mathrm{S}=10\right)$.

\begin{tabular}{ccccccc}
\hline Element & Zn & Cr & Mn & Fe & Cd & Pb \\
\hline $\mathrm{mg} / \mathrm{dm}^{3}$ & 15190 & 40 & 12 & 20 & 12 & 420 \\
\hline
\end{tabular}

\subsection{Cementation}

The removal of undesirable elements from the electrolyte is necessary for the final stage of processing: Electrolysis. In the electrolysis process, any metal more noble than zinc will be deposited on the cathode, contaminating the zinc cathode and reducing the current efficiency. Therefore, it is important that the solution used for electrolysis contains the least amount of undesirable metals. The cementation process can be written in the general form of Equation (6):

$$
n_{2} \mathrm{Me}^{n_{1}+}+n_{1} \mathrm{M}^{0}=n_{2} \mathrm{Me}^{0}+n_{1} \mathrm{M}^{n_{2}+}
$$

where: $n_{1}, n_{2}$ is the ion charge; Me is the cementated metal; and $\mathrm{M}$ is the cementing metal.

According to the above reaction it is possible to remove more noble metals with zinc, and in this particular case, mainly a significant amount of lead. Figure 8 shows the changes in the concentration of zinc and lead throughout the 70-min cementation process.

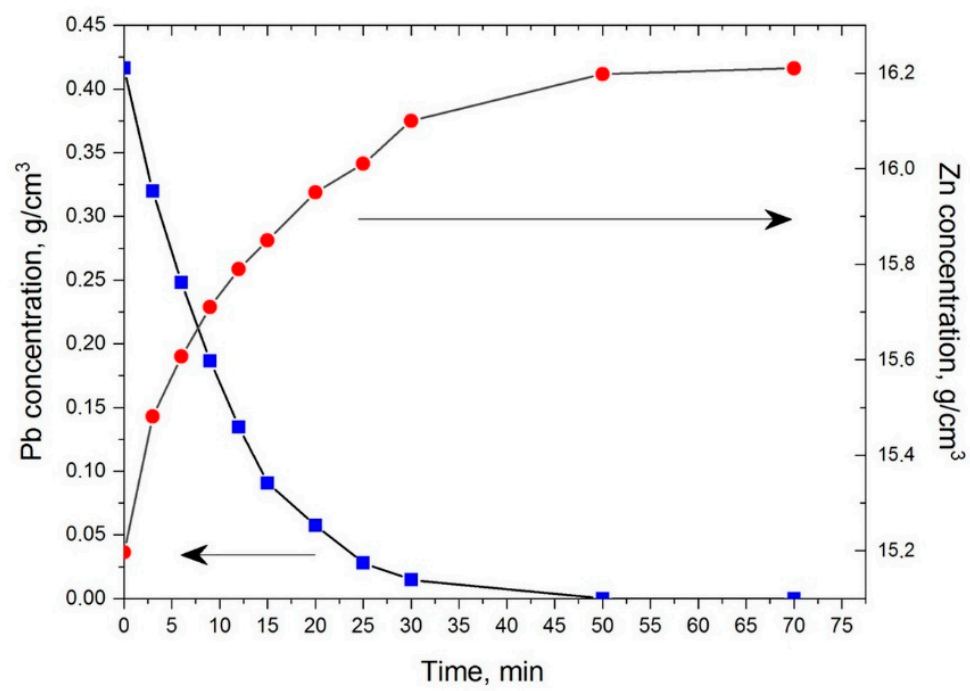

Figure 8. Concentration of $\mathrm{Pb}$ (blue) and $\mathrm{Zn}$ (red) during the cementation process. 
As can be seen from Figure 8, practically all lead was removed in just 50 min. The concentration of other metals remained unchanged during the cementation process. The lead concentration in the solution after cementation $\left(<10 \mathrm{mg} / \mathrm{dm}^{3}\right)$ was found to be low enough to not affect zinc electrolysis. It should be noted here for comparison that Orhan [13] studied the effectiveness of the cementation process using zinc powder. Despite the selection of optimal process parameters, even after $3 \mathrm{~h}$ of cementation, lead was removed from the solution to a level of $100-120 \mathrm{mg} / \mathrm{dm}^{3}$. Furthermore, Mordogan et al. in Reference [10], who also used zinc powder, removed lead from the solution to the level of about $210 \mathrm{mg} / \mathrm{dm}^{3}$ using zinc powder. Table 4.

The composition of the post-cementation solution which was used for electrolysis is presented in

Table 4 . The composition of the solution after the cementation process.

\begin{tabular}{ccccccc}
\hline Element & $\mathbf{Z n}$ & $\mathbf{C r}$ & $\mathbf{M n}$ & $\mathbf{F e}$ & $\mathbf{C d}$ & $\mathbf{P b}$ \\
\hline $\mathrm{mg} / \mathrm{dm}^{3}$ & 16200 & 40 & 12 & 20 & 12 & $<10$ \\
\hline
\end{tabular}

\subsection{Electrolysis}

The reactions which occur during the process of electrolysis can be written in the following form:

$$
\begin{gathered}
\mathrm{A}(+): 2 \mathrm{OH}^{-} \rightarrow 1 / 2 \mathrm{O}_{2}+\mathrm{H}_{2} \mathrm{O}+2 \mathrm{e} \\
\mathrm{K}(-): \mathrm{Zn}(\mathrm{OH})_{4}{ }^{2-}+2 \mathrm{e} \rightarrow \mathrm{Zn}+2 \mathrm{OH}^{-}+\mathrm{H}_{2} \mathrm{O}
\end{gathered}
$$

In total, the process of metallic zinc deposition from the solution can be written as:

$$
\mathrm{Na}_{2} \mathrm{ZnO}_{2}+\mathrm{H}_{2} \mathrm{O} \rightarrow \mathrm{Zn}+2 \mathrm{NaOH}+1 / 2 \mathrm{O}_{2}
$$

Since the concentration of elements in the electrolyte was low (Table 4), the process of electrolysis was straightforward. The result was a spongy powder, having a morphology as shown in Figure 9.

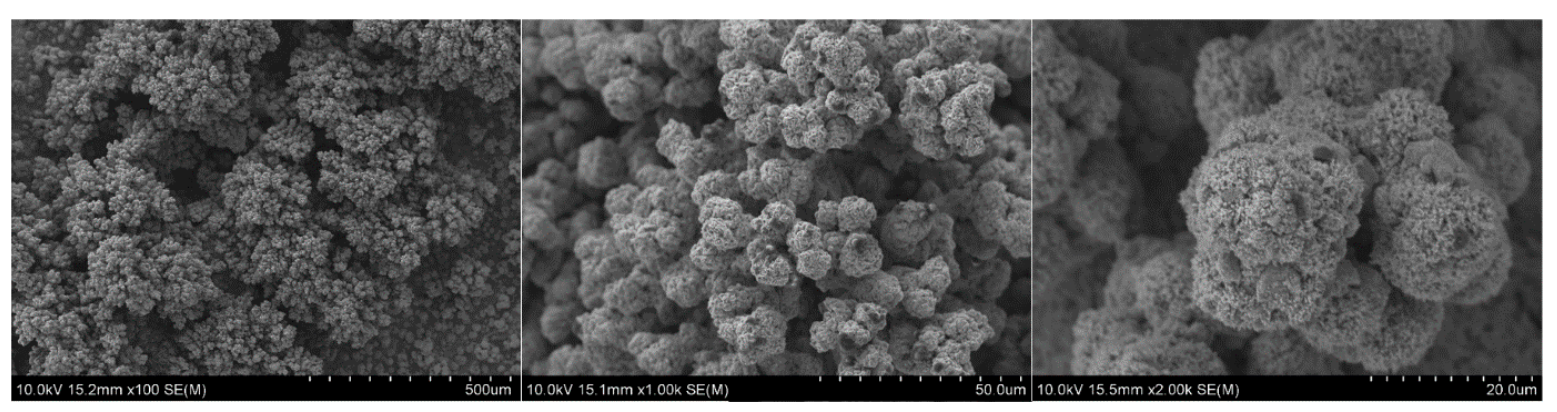

Figure 9. Images of zinc powder deposited on cathode; SEM.

The process efficiency with the applied current density of $250 \mathrm{~A} / \mathrm{m}^{2}$ was $86 \%$. A similar value under similar experimental conditions was obtained by Zhang et al. [17], but there was no mention of the structure of the cathode deposit and purity of the obtained zinc. The chemical composition of the zinc deposited on the cathode from the present study is given in Table 5.

Table 5. Chemical composition of the cathodic zinc.

\begin{tabular}{cc}
\hline Compound & Concentration, $\%$ \\
\hline $\mathrm{Fe}$ & 0.064 \\
$\mathrm{Cd}$ & 0.051 \\
$\mathrm{Zn}$ & 99.88 \\
\hline
\end{tabular}


The deposit obtained in this study was easy to remove from the cathode surface and, as shown by the analysis in Table 5, had a high degree of purity. The deposit was repeatedly rinsed with distilled water before the analysis was free of sodium.

\section{Discussion}

Currently, in terms of development, the hydrometallurgical technologies are lagging behind the pyrometallurgical processes used in most industrial installations for the processing of steelmaking dust. Nevertheless, studies of hydrometallurgical techniques for zinc recycling from this type of waste are still ongoing and have become important for several reasons:

- Hydrometallurgical processes are environmentally friendly, generating practically no air pollution.

- Installations are much smaller in size compared to pyrometallurgical plants, and as such require lower investment and operating costs.

- Hydrometallurgical processes are applicable in the recovery of other valuable metals.

- The product obtained from leaching is an iron-bearing material that can be recycled and reused in the steelmaking process (if the zinc content will be at the minimum level).

As shown by this study, leaching with $\mathrm{NaOH}$ solution is selective towards zinc, and the process proceeds with a high yield of up to $88.0 \%$. However, the presence of zinc in the form of $\mathrm{ZnFe}_{2} \mathrm{O}_{4}$ ferrite poses some problems in regards to its complete recovery from steelmaking dust. Studies have shown that even high concentrations of $\mathrm{NaOH}(6 \mathrm{M})$, high temperature $\left(80^{\circ} \mathrm{C}\right)$, and adequate excess of leaching solution in relation to the solid phase $(\mathrm{L} / \mathrm{S}=40)$ does not remove all of the zinc present. Although the results of the XRD analysis of the leach residue, generated in 4 and $6 \mathrm{M} \mathrm{NaOH}$ at a temperature of $80^{\circ} \mathrm{C}$, indicated that zinc ferrite dissolution does occur, the rate of this reaction is low. Xia and Pickles [11] found that even in a highly aggressive leaching environment $(10 \mathrm{M} \mathrm{NaOH}$, temperature of $93^{\circ} \mathrm{C}$, leaching time of $3 \mathrm{~h}$ ), the extraction yield of zinc from the zinc ferrite is only $9 \%$. A solution to this problem might be sintering of dusts with $\mathrm{Na}_{2} \mathrm{CO}_{3}$ before the leaching process, in order to decompose the zinc ferrite according to reaction (10), as suggested by Holloway et al. [18].

$$
\mathrm{ZnFe}_{2} \mathrm{O}_{4}+\mathrm{Na}_{2} \mathrm{CO}_{3} \rightarrow \mathrm{ZnO}+2 \mathrm{NaFeO}_{2}+\mathrm{CO}_{2}
$$

Another solution may be to grind the EAF dust with iron powder (mechanochemical reduction). This also enables the breakdown of $\mathrm{ZnFe}_{2} \mathrm{O}_{4}$, as demonstrated by Zhang et al. [19]. Such approaches generate additional costs due to the expansion of the installations to include aggregates for material processing, such as mills, furnaces and dryers, but the end product-i.e., an iron-bearing material-is free from zinc (or has only a very low content of this metal), and thus can be returned to the steelmaking process. The results of cementation and electrolysis presented in this study showed that both processes run smoothly to give a high purity final product.

\section{Conclusions}

1. Leaching of EAF dust using $\mathrm{NaOH}$ solutions confirmed high zinc selectivity.

2. All parameters tested (time, temperature, $\mathrm{L} / \mathrm{S}$ ratio and $\mathrm{NaOH}$ concentration) had a positive effect on the efficiency of zinc leaching.

3. Increasing the leachate content in relation to the solid phase content increases the leaching efficiency, but also decreases the zinc concentration in the solution. This means that it is necessary to handle larger volumes of solution to obtain the required EAF dust throughput.

4. The maximum zinc leaching efficiency of $88.0 \%$ was achieved in a $6 \mathrm{M} \mathrm{NaOH}$ solution at a leaching temperature of $80^{\circ} \mathrm{C}$ and $\mathrm{L} / \mathrm{S}=40$. Complete leaching of zinc from steelmaking dust under the tested conditions was not possible due to the presence of this element in the form of $\mathrm{ZnFe}_{2} \mathrm{O}_{4}$. 
5. The cementation process using metallic zinc enables the removal of lead from the solution to a very low level of concentration $\left(<10 \mathrm{mg} / \mathrm{dm}^{3}\right)$.

6. The cathode zinc was obtained as spongy-powder and is characterized by high purity $(99.88 \%)$.

Author Contributions: Conceptualization, writing the manuscript, investigation-Piotr Palimaka; Data analysis-S.P.; Investigation, MP-AES analysis-M.S.; Leaching test-K.C.; SEM analysis-I.N. All authors have discussed the results, read and approved the final manuscript.

Acknowledgments: This paper is supported by the Ministry of Science and Higher Education (Grant No.11.11.180.959).

Conflicts of Interest: The authors declare no conflict of interest.

\section{Appendix A}

Table A1. Results of leaching experiments after $120 \mathrm{~min}$.

\begin{tabular}{|c|c|c|c|c|c|c|c|c|c|c|}
\hline $\mathrm{L} / \mathrm{S}, \mathrm{cm}^{3} / \mathrm{g}$ & Temp., ${ }^{\circ} \mathrm{C}$ & $C_{\mathrm{NaOH}}, \mathbf{M}$ & $L_{e}, \%$ & $C_{\mathrm{Zn}}, \mathrm{g} / \mathrm{cm}^{3}$ & $C_{\mathrm{NaOH}}, \mathbf{M}$ & $L_{e}, \%$ & $C_{\mathrm{Zn}}, \mathrm{g} / \mathrm{cm}^{3}$ & $C_{\mathrm{NaOH}}, \mathbf{M}$ & $L_{e}, \%$ & $C_{\mathrm{Zn}}, \mathrm{g} / \mathrm{cm}^{3}$ \\
\hline \multirow{3}{*}{10} & 20 & & 16.5 & 5.4 & & 31.6 & 10.4 & & 39.5 & 13.0 \\
\hline & 50 & & 21.2 & 7.0 & & 34.5 & 11.4 & & 42.0 & 13.9 \\
\hline & 80 & & 24.0 & 7.9 & & 40.6 & 13.4 & & 46.0 & 15.2 \\
\hline \multirow{3}{*}{20} & 20 & & 28.3 & 4.7 & & 45.4 & 7.9 & & 51.4 & 8.5 \\
\hline & 50 & & 39.3 & 6.4 & & 58.1 & 10.2 & & 56.0 & 9.9 \\
\hline & 80 & 2 & 44.8 & 7.4 & 4 & 68.2 & 12.2 & 6 & 70.3 & 11.6 \\
\hline \multirow{3}{*}{30} & 20 & & 38.1 & 4.2 & & 55.2 & 6.6 & & 59.6 & 6.6 \\
\hline & 50 & & 53.6 & 5.9 & & 70.1 & 7.7 & & 71.2 & 7.8 \\
\hline & 80 & & 59.8 & 6.7 & & 79.1 & 8.7 & & 80.0 & 8.8 \\
\hline \multirow{3}{*}{40} & 20 & & 50.0 & 4.1 & & 65.1 & 5.5 & & 68.1 & 5.6 \\
\hline & 50 & & 62.2 & 5.1 & & 78.1 & 6.4 & & 79.1 & 6.5 \\
\hline & 80 & & 70.1 & 5.8 & & 85.0 & 7.2 & & 88.0 & 7.2 \\
\hline
\end{tabular}

\section{References}

1. Guézennec, A.G.; Huber, J.C.; Patisson, F.; Sessiecq, P.; Birat, J.P.; Ablitzer, D. Dust formation in Electric Arc Furnace: Birth of the particles. Powder Technol. 2005, 157, 2-11. [CrossRef]

2. Ostrowska, P.; Mierzwa, K. Recovery of zinc from selected metallurgical waste. Hutnik-WH 2007, 64, 369-373.

3. Woźniacki, Z.; Telejko, T.K. Sintering as the method of utilization of steelmaking dusts with a high content of zinc oxides. Hutnik-WH 2014, 81, 166-171.

4. Stevart, C. Sustainability in Action: Recovery of Zinc from EAF Dust in the Steel Industry, 2015 Intergalva Conference, Liverpool, England, June 2015. Available online: http:/ /www.icz.org.br/upfiles/arquivos / apresentacoes/intergalva-2015/5-2-Stewart.pdf (accessed on 24 April 2018).

5. Palimaka, P.; Pietrzyk, S.; Stepien, M. Recycling of Zinc from the Steelmaking Dust in the Sintering Process. In Energy Technology 2017, The Minerals, Metals \& Materials Series; Zhang, L., Drelich, J.W., Neelameggham, N.R., Eds.; Springer International Publishing AG: Cham, Switzerland, 2017; pp. 181-189, ISBN 978-3-319-52191-6.

6. Maccagni, M.G. INDUTEC/EZINEX Integrate Process on Secondary Zinc-Bearing Materials. J. Sustain. Metall. 2016, 2, 133-140. [CrossRef]

7. Nakamura, T.; Shibata, E.; Takasu, U.T.; Itou, H. Basic consideration on EAF dust treatment using hydrometallurgical processes. Resour. Process. 2008, 55, 144-148. [CrossRef]

8. Díaz, G.; Martín, D. Modified Zincex process: The clean, safe and profitable solution to the zinc secondaries treatment. Resour. Conserv. Recycl. 1994, 10, 43-57. [CrossRef]

9. Xia, K. Recovery of Zinc From Zinc Ferrite and Electric Arc Furnace Dust. Ph.D. Thesis, Department of Materials and Metallurgical Engineering, Queen's University, Kingston, ON, Canada, Septemper 1997.

10. Mordoğan, H.; Çïçek, T.; Işik, A. Caustic soda leach of electric arc furnace dust. Turkish J. Eng. Environ. Sci. 1999, 23, 199-207.

11. Xia, D.K.; Pickles, C.A. Kinetics of zinc ferrite leaching in caustic media in the deceleratory period. Miner. Eng. 1999, 12, 693-700. [CrossRef]

12. Dutra, A.J.B.; Paiva, P.R.P.; Tavares, L.M. Alkaline leaching of zinc from electric arc furnace steel dust. Miner. Eng. 2006, 19, 478-485. [CrossRef] 
13. Orhan, G. Leaching and cementation of heavy metals from electric arc furnace dust in alkaline medium. Hydrometallurgy 2005, 78, 236-245. [CrossRef]

14. Stefanova, A.; Aromaa, J. Alkaline Leaching of Iron and Steelmaking Dust. Research Raport, Aalto University publication series SCIENCE + TECHNOLOGY 1/2012. Available online: https:/ /aaltodoc.aalto.fi/handle/ 123456789/3570 (accessed on 24 April 2018).

15. Havlik, T.; Kukurugya, F.; Miskufova, A.; Parilak, L.; Jascisak, J. Leaching of EAF Steelmaking Dust in Sulfuric Acid Dilute Solution: Case of Calcium. In Proceedings of the 2015 Sustainable Industrial Processing, Antalya, Turkey, 4-9 October 2015; pp. 81-88.

16. Erdem, M.; Yurten, M. Kinetics of $\mathrm{Pb}$ and $\mathrm{Zn}$ leaching from zinc plant residue by sodium hydroxide. J. Min. Metall. Sect. B Metall. 2015, 51, 89-95. [CrossRef]

17. Zhang, Y.; Deng, J.; Chen, J.; Yu, R.; Xing, X. The electrowinning of zinc from sodium hydroxide solutions. Hydrometallurgy 2014, 146, 59-63. [CrossRef]

18. Holloway, P.C.; Etsell, T.H.; Murland, A.L. Roasting of La Oroya zinc ferrite with $\mathrm{Na}_{2} \mathrm{CO}_{3}$. Metall. Mater. Trans. B Process. Metall. Mater. Process Sci. 2007, 38, 781-791. [CrossRef]

19. Zhang, C.; Zhuang, L.; Wang, J.; Bai, J.; Yuan, W. Extraction of zinc from zinc ferrites by alkaline leaching: Enhancing recovery by mechanochemical reduction with metallic iron. J. South. African Inst. Min. Metall. 2016, 116, 1111-1114. [CrossRef]

(C) 2018 by the authors. Licensee MDPI, Basel, Switzerland. This article is an open access article distributed under the terms and conditions of the Creative Commons Attribution (CC BY) license (http:/ / creativecommons.org/licenses/by/4.0/). 